\title{
Tillage and Cover Residue Affects on Vegetable Yields
}

Greg D. H oyt

AdDITIONAL INDEX WORDS. cabbage, tomato, squash, broccoli, potato, snap beans, cover crops, soil temperature, no till, strip till

SUMmARY. The availability of various conservation tillage (CT) practices along with a variety of cover residues creates an opportunity for farm managers to create new systems for vegetable production. We established various tillage practices and cover crop residues for CT use to determine which systems would continue to deliver high vegetable productivity. Recommendations for using CT based only on a yield perspective would lead us to conclude that full season crops could be grown with some form of $\mathrm{CT}$ and respectable yields would be obtainable. Tomato (Lycopersicon esculentum Mill.) production with CT is successfully being practiced in North Carolina in both the mountain valleys and Piedmont region. Because of the cooler soil temperatures with cover residue, summer and especially fall harvested tomatoes produce the least risk in obtaining similar yields as plow/ disc production. 0 ur experiments with short season vegetable crops and CT have had mixed results. Cole crops (Brasica L.) grown with CT in early spring or late fall experience soil temperatures cool enough to delay growth compared to plow/ disc management. Proper selection of a cover crop residue type and the amount of cover residue can increase yield. G rowing short season vegetable crops with CT during the warmest season of the year will reduce the risk of delayed plant growth and thus, decrease the time to harvest.

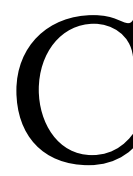

onservation tillage (CT) has become an accepted cultural practice for many seeded agronomic crops since its introduction in the 1950s. Acceptance can be attributed to a combination of events occurring concurrently, including improved herbicide development and use, concern for soil erosion, and innovative equipment modifications. H orticultural crops have not been studied as thoroughly as agronomic crops in CT experiments (H oyt et al., 1994).

The introduction of a no-till transplanter has provided a means for planting bare rooted or containerized transplants in undisturbed soil (M orrison et al., 1973). D irect seeded vegetables such as sweet corn (Zea mays L.), dry beans (PhaseolusL.), and squash (C ucurbita L.) can be planted easily by current no-till seeders designed for agronomic row crops [corn and soybeans (Glycine max L.)]. Prior no-till experiments with vegetables have resulted in various degrees of success depending on location, year, moisture, and other factors.

D epartment of Soil Science, N orth Carolina State U niversity, M ountain H orticultural Crops Research and Extension Center, 2016 Fanning Bridge Road, Fletcher, N C 28732.

The N orth C arolinaA gricultural Research Service supported thisresearch. EmeritusProfessors Thomas R. Konsler and Frank L. H aynes provided leadership in cole crops and potatoes. Anthony D. Cole and G eorge B. Cox provided technical assistance. Thanks to M orris $\mathrm{H}$ ylemon and the staff at the $\mathrm{M}$ ountain $\mathrm{H}$ orticultural $\mathrm{C}$ rops Research Station for maintaining the field plots. U se of trade names in this publication does not imply endorsement by the North Carolina Agricultural Research Service, nor criticism of similar ones not mentioned. This publication reports research involving pesticides. It does not contain recommendationsfor their use, nor does it imply that the uses discussed here have been registered. All uses of pesticides must be registered by appropriate State and Federal Agencies before they can be recommended. The cost of publishing this paper was defrayed in part by the payment of page charges. U nder postal regulations, this paper therefore must be hereby marked advertisement solely to indicate this fact. 
In Kentucky, Knavel et al. (1977) obtained greater sweet corn and popcorn yields (Knavel et al., 1985) with no-till culture than with conventional tillage. CT improved or maintained yields similar to conventional tillage in tomatoes (Beste, 1973; H egwood et al., 1978; Morse et al., 1982), field beansand peppers (C apsicum annuum L.) (Lugo-M ercando et al., 1984; M orseet al., 1982), potatoes (Sol anum tuber osum L.) (H oyt and M onks, 1996; $M$ undy et al., 1999), cabbage (Bras sica ol eracea L. Capitata Group) and broccoli (Brassica oleracea L. I talica Group) (Hoyt et al., 1996; Morse, 1993; Morse and Steward, 1986; Wilhoit et al., 1990), and lima beans (Phaseolus lunatus L.) (Beste, 1973). Conversely, lower yields with CT were obtained with cucumber (CucumissativusL.), tomato, and peppers (Beste, 1973; Knavel et al., 1977), cabbage ( $H$ oyt and Walgenbach, 1995; Knavel and $\mathrm{H}$ erron, 1981, 1985), potatoes (Mundy et al., 1999), snapbeans (PhaseolusvulgarisL.), (Bottenberg et al., 1999) and carrot (D aucus carota L.) (Cambell and Anderson, 1980).

The benefits of surface residues or mulch in conserving soil moisture in horticultural crops has been known for many years (Emerson, 1903) with materials such as black plastic emulating thebenefits of crop residues(Esteset al., 1985). Growing winter cover crops for surface residues in $\mathrm{CT}$ provides mulch that may decrease soil temperature and influence vegetable yields, depending on cover residue selection (Coolman and $\mathrm{H}$ oyt, 1993; H oyt and Konsler, 1988; Knavel and H erron, 1985). Legume residues have increased vegetable yields when compared to grass residues (H oyt and $\mathrm{H}$ argrove, 1986) and have increased nitrogen (through biological nitrogen fixation), potassium, and phosphorus recycling within the soil horizon (M orse and Steward, 1985; Wagger, 1993). Winter cover grass residues can produce similar yields as legume cover residues with $C T$ if fertilizer nitrogen is adequately supplied (H oyt, 1984; Ranells and Wagger, 1997).

The following experiments integrate both degree of tillage and type of cover crop residue in CT to identify tillage systems that work for specific vegetables. All experiments were conducted at the M ountain $\mathrm{H}$ orticultural C ropsR esearch Station, F letcher, N .C., in the mountain region of the southeastern U nited States.

\section{Tillage effects on vegetable growth}

Four vegetableexperimentsusing snapbeans, winter squash, broccoli, and tomatoes were established in the same field location. All experiments were planted into a $D$ elanco loam soil (fine loamy, mixed, mesic AquicH apludults) using a no-till planter (John Deere $M$ axEmerge; Deere and Company, M oline, III.) on all treatments for the snapbean and squash seeded crops. A barley ( $\mathrm{H}$ ordeum vulgareL.) cover crop $\left[6000 \mathrm{lb} /\right.$ acre $\left(6725 \mathrm{~kg} \cdot \mathrm{ha}^{-1}\right)$ dry matter] was killed by applying paraquat at $1 \mathrm{qt} /$ acre $\left(2.3 \mathrm{~L} \cdot \mathrm{ha}^{-1}\right) 2$ weeks before planting. The three tillage treatments were plow/ disc, strip till, and no till with four replications for each tillage treatment. The plow/ disc treatment was established 2 weeks before planting by plowing the entire plot [30 $\mathrm{ft}$ $(9.1 \mathrm{~m})$ long with $10 \mathrm{ft}(3.0 \mathrm{~m})$ endrow border] with a moldboard plow [tillage to 9 inches $(23 \mathrm{~cm})$ depth] and then discing twice. The strip-till treatment was prepared by using a Bush $\mathrm{H}$ og (Selma, Ala.) Ro-till [tillage to 12 inches $(30 \mathrm{~cm})$ depth] $2 \mathrm{~d}$ before planting. The strip-till treatment created an 8- to 12 -inch-wide $(20$ to $30 \mathrm{~cm}$ ) tilled area on the surface. The no-till treatment used no prior tillage. Fertilizer $P$, $\mathrm{K}$, and limestone was applied according to $\mathrm{N}$ orth $\mathrm{C}$ arolina Agronomic D ivision soil test recommendations before planting the cover crop. Over head irrigations of $0.75 \mathrm{inch} / \mathrm{acre}(1.9$ $\mathrm{cm} \cdot \mathrm{ha}^{-1}$ ) were applied $1 \mathrm{~h}$ after planting and 1 and 2 weeks after planting. $M$ eans were separated with Fisher's least significant difference (LSD) test at the $5 \%$ level of significance (SAS I nstitute, 1988).

Snap beans. 'BlueL ake' snapbeans were planted on $23 \mathrm{M}$ ay to determine the effect of plow/ disc, strip till, and no till on earliness of pod yield. Plots were four rows wide with a betweenrow spacing of $3 \mathrm{ft}(0.9 \mathrm{~m})$ and final (after thinning) in-row spacing of 2 inches $(5 \mathrm{~cm})$. Fertilizer nitrogen was broadcast surface applied at a rate of $70 \mathrm{lb} /$ acre N $\left(78.5 \mathrm{~kg} \cdot \mathrm{ha}^{-1}\right) 1 \mathrm{~d}$ before planting and banded on the soil surface at $30 \mathrm{lb} /$ acre $\mathrm{N}\left(33.6 \mathrm{~kg} \cdot \mathrm{ha}^{-1}\right) 2$ weeks later. An application of metolachlor [D ual at 1 qt/ acre $(2.3$ $\left.L \cdot h a^{-1}\right)$ ] and dinoseb [Premerge at 1 gal/ acre $\left(9.4 \mathrm{~L} \cdot \mathrm{ha}^{-1}\right)$ ] 1 week after seeding was used for summer weed control.

Snap beans were harvested every $3 \mathrm{~d}$ for seven harvests. Cumulative yields increased as follows: plow/ disc $>$ strip till > no till (Fig. 1). H owever, on the fifth harvest strip-till and no-till yields began to increase compared to the plow/ disc treatment, and by the final harvest the two $\mathrm{CT}$ treatments equaled the plow/ disc treatment (no significant differences among treatments at harvest).

Winter SQUASH. A winter squash experiment was planted near the snap

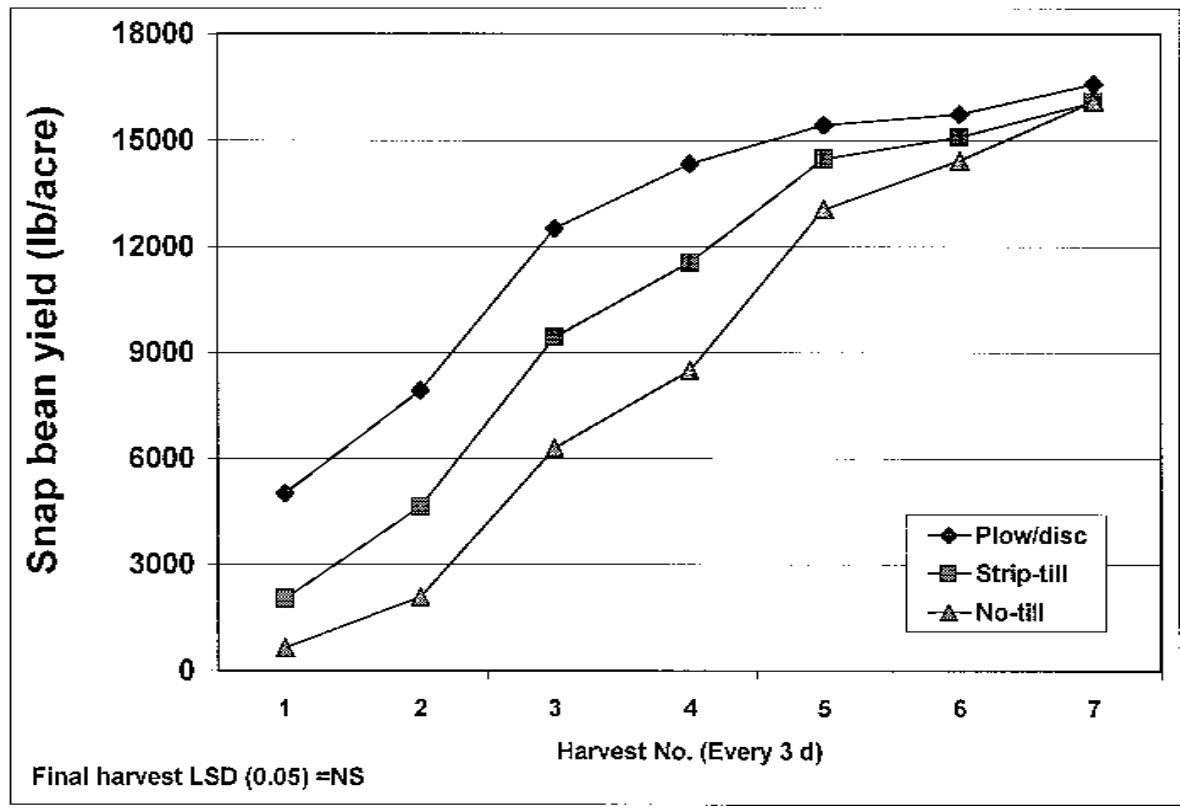

Fig. 1. C umulative snap bean yields of plow/disc, strip-till, and no-till culture; $1 \mathrm{lb} / \mathrm{acre}=1.12 \mathrm{~kg}^{\prime} \mathrm{ha}^{-1}$. 


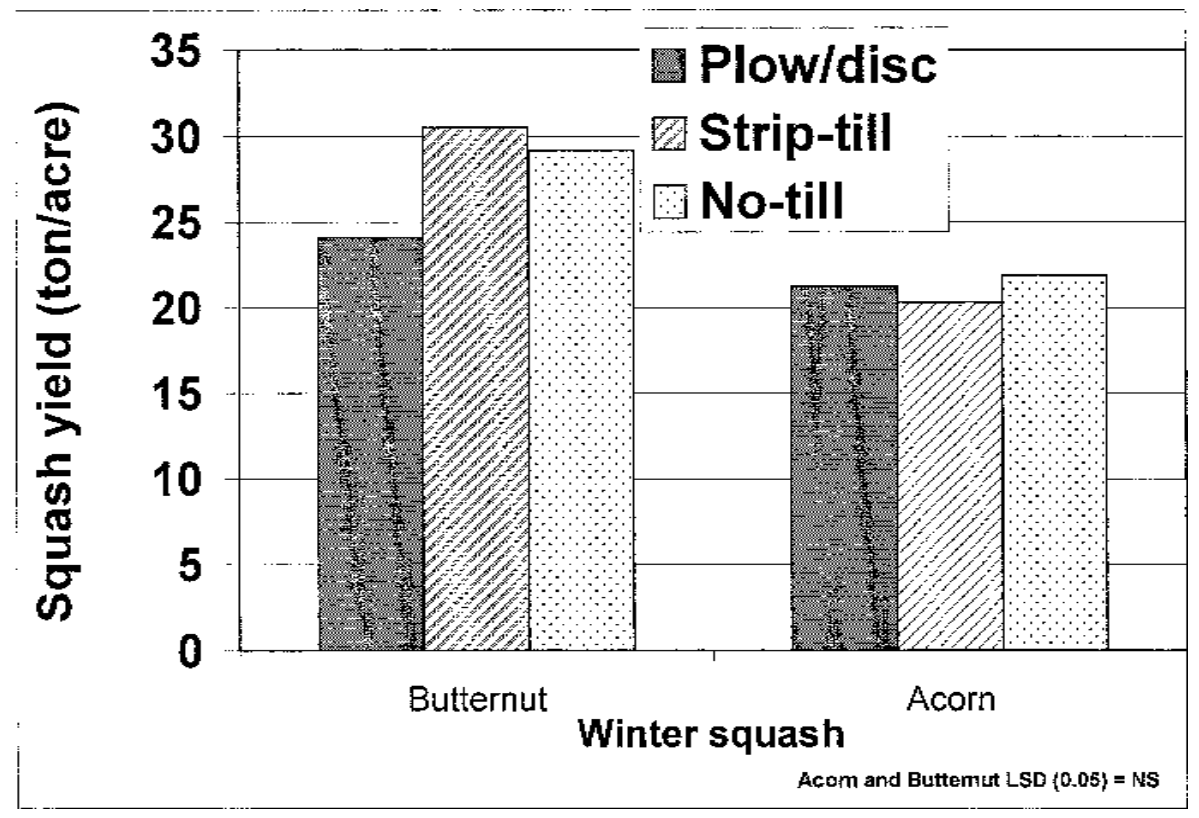

Fig. 2. Effect of plow/disc, strip-till, and no-till culture on butternut and acorn winter squash yields; 1 ton/acre $=2.24 \mathrm{t} \cdot \mathrm{ha}^{-1}$.

bean experiment in the same soil type. This experiment measured the effect of tillage on a full season vegetable crop where only a single end of season harvest was taken. 'T able Ace' acorn squash and 'Early Butternut' butternut squash were planted on $23 \mathrm{M}$ ay in separate, but similar locations with a no-till planter (John Deere $M$ axE merge) fitted with a feed cup assembly to match the two sizes of seeds. The three tillage practices were plow/ disc, strip till, and no till. Plots were four rows wide with a betweenrow spacing of $5.5 \mathrm{ft}(1.7 \mathrm{~m})$ and final (after thinning) in-row spacing of $2 \mathrm{ft}$ $(0.6 \mathrm{~m})$. Fertilizer nitrogen was broadcast surface applied at a rate of $50 \mathrm{lb} /$ acreN $\left(56.0 \mathrm{~kg} \cdot \mathrm{ha}^{-1}\right) 1 \mathrm{~d}$ after planting and two surface-banded sidedress applications were applied at a rate of 30 $\mathrm{lb} /$ acreN $\left(33.6 \mathrm{~kg} \cdot \mathrm{ha}^{-1}\right) 2$ and 4 weeks after planting. An application of napropamide [D evrinol 50WP at $2 \mathrm{lb} /$ acre $\left.\left(2.2 \mathrm{~kg} \cdot \mathrm{ha}^{-1}\right)\right]$ and chloramben [Amiben at $1.5 \mathrm{gal} / \mathrm{acre}\left(14.0 \mathrm{~L} \cdot \mathrm{ha}^{-1}\right)$ ] was applied 1 week after planting.

Squash yields for both varieties were high with no statistical differences among the three tillage treatments for either variety (Fig. 2).

Broccoll. 'Green D uke' broccoli was planted in the same field and soil type as the snap bean and squash trials. This experiment measured the effect of tillage on broccoli yield when transplanted in both a spring and fall planting. Spring broccoli was transplanted on $7 \mathrm{M}$ ay and fall broccoli was transplanted on $7 \mathrm{Aug}$. The three tillage practices were plow/ disc, strip till, and no till. All broccoli transplants were planted with a hand trowel into thethreetillagetreatments. Plotswere four rows wide with a between-row spacing of 36 inches $(91 \mathrm{~cm})$ and inrow spacing of $1 \mathrm{ft}(0.3 \mathrm{~m})$. Fertilizer nitrogen was broadcast surface applied at a rate of $80 \mathrm{lb} /$ acre $\mathrm{N}\left(89.7 \mathrm{~kg} \cdot \mathrm{ha}^{-1}\right)$ $1 \mathrm{~d}$ before planting and $35 \mathrm{lb} /$ acre N $\left(39.2 \mathrm{~kg} \cdot \mathrm{ha}^{-1}\right)$ as a banded side dress 2 weeks after transplanting. An application of napropamide [D evrinol 50WP at $4 \mathrm{lb} /$ acre $\left(4.5 \mathrm{~kg} \cdot \mathrm{ha}^{-1}\right)$ ] broadcast over the entire plot and oxyfluorfen [G oal $1.6 \mathrm{E}$ at $0.5 \mathrm{lb} / \mathrm{acre}\left(0.6 \mathrm{~kg} \cdot \mathrm{ha}^{-1}\right)$ ] applied between the rows $1 \mathrm{~d}$ after planting was used for summer weed control. The stale barley cover crop that was killed in the spring but left standing was used as cover residue for fall broccoli production (separate location to the spring broccoli experiment). G lyphosate[Roundup at $2 \mathrm{qt} /$ acre $\left.\left(4.7 \mathrm{~L} \cdot h \mathrm{a}^{-1}\right)\right]$ was applied to kill summer weeds and any barley not yet senesced. Napropamide and oxyfluorfen herbicides were applied similar to the spring production methods.

Spring broccoli production produced greater yields than fall broccoli production (Fig. 3). In both experiments, greater broccoli yields were obtained from the plow/ disc compared to the strip-till and no-till treatments, with similar yields in the striptill and no-till treatments.

Tомато. 'M ountain Pride' fresh market tomatoes were used to determine the effect of tillage on tomato fruit yield. Six tillage practices were established that included two tillage treatments that tilled the entire plot [plow/disc (described above) and rotavate [the entire plot tilled to a depth of 6 inches $(15 \mathrm{~cm})$ with a $\mathrm{H}$ oward Rotavator (H oward R otavator Co., N apa, Calif.)], two strip-tillage

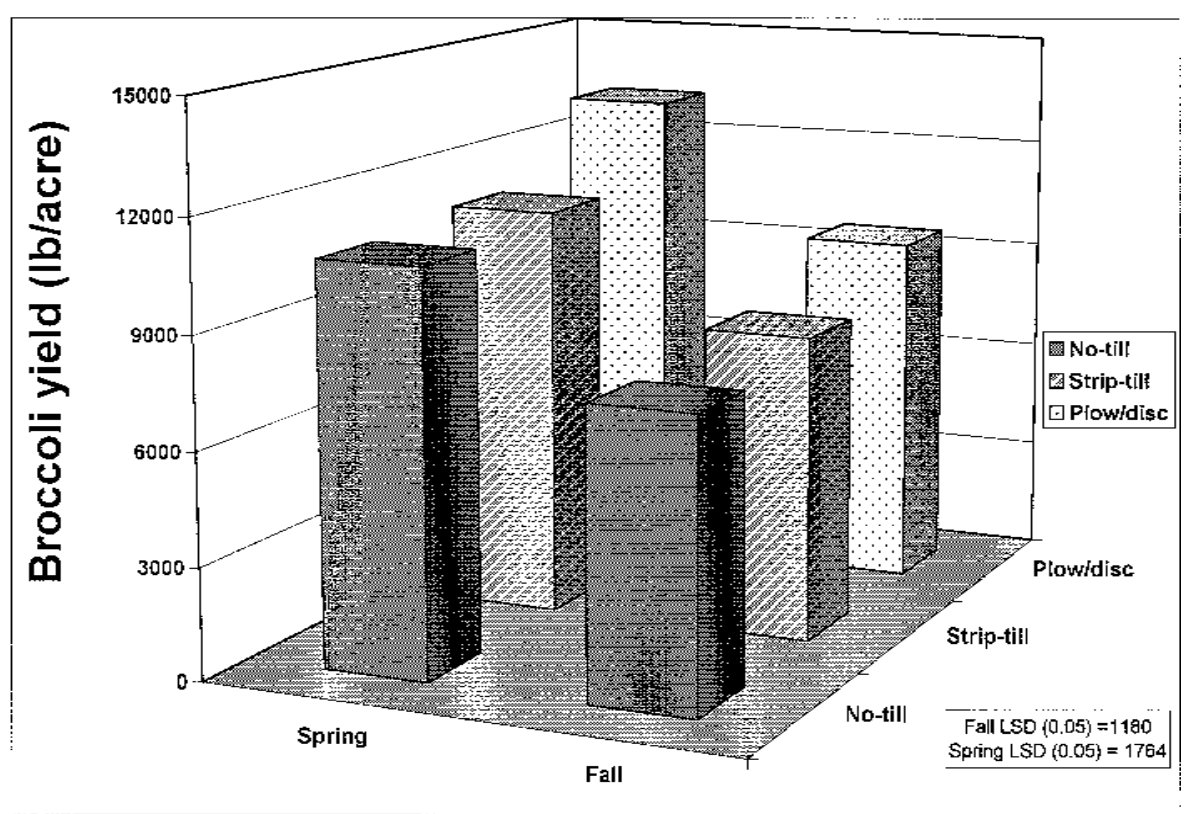

Fig. 3. Effect of plow/disc, strip-till, and no-till culture on spring and fall broccoli yields; $1 \mathrm{lb} / \mathrm{acre}=1.12 \mathrm{~kg} \cdot \mathrm{ha}^{-1}$. 


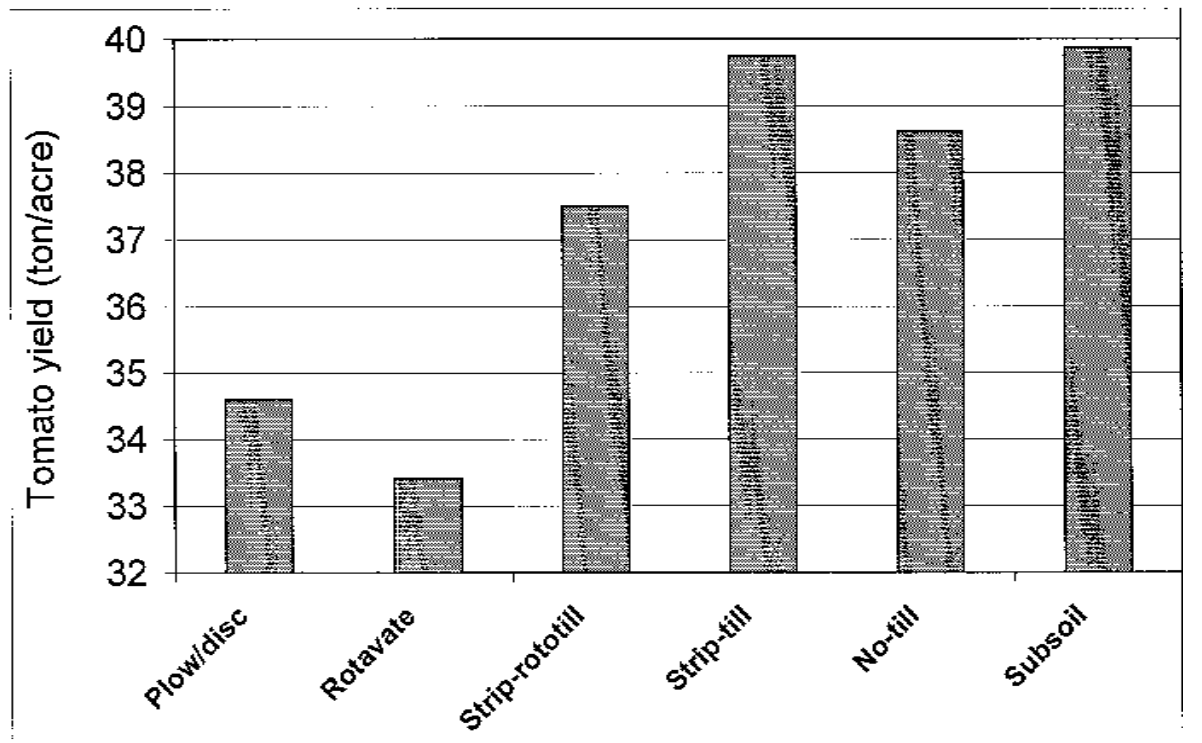

Tillage method

$\operatorname{LSD}(0,05)=6,09$

Fig. 4. T omato yields from plow/disc, rotavated, strip-rototill, strip-till, no-till, and subsoil tillage treatments; 1 ton/acre $=2.24 \mathrm{t} \cdot \mathrm{ha}^{-1}$. treatments [strip till (described above) and strip rototill [the in-row strip-till area was tilled with a garden rototiller, creating a tilled area 15 inches $(38 \mathrm{~cm})$ wide and tilled to a depth of 6 inches $(15 \mathrm{~cm})]$, and two nontillage treatments [no till (plants were planted with a hand trowel using no preplant tillage) and subsoil (a subsoil shank tilling to a depth of 8 inches $(20 \mathrm{~cm})$ was run in-row below where the tomato transplants were planted) ]. Plots were three rows wide with a betweenrow plant spacing of $5 \mathrm{ft}(1.5 \mathrm{~m})$ and in-row spacing of $2 \mathrm{ft}(0.6 \mathrm{~m})$. Fertilizer nitrogen was broadcast surface applied at a rate of $100 \mathrm{lb} /$ acre $\mathrm{N}$ (112.1 kg $\left.\cdot \mathrm{ha}^{-1}\right) 1 \mathrm{~d}$ before planting, and two $50 \mathrm{lb} /$ acre N (56.0 kg $\left.\cdot \mathrm{ha}^{-1}\right)$ surface banded side dress applications 2 and 4 weeks after transplanting. An application of metribuzin [Sencor $75 \mathrm{DF}$ at $1 \mathrm{lb} /$ acre $\left.\left(1.1 \mathrm{~kg} \cdot \mathrm{ha}^{-1}\right)\right]$ and napropamide [D evrinol 50WP at 2 $\mathrm{lb} /$ acre $\left.\left(2.2 \mathrm{~kg} \cdot \mathrm{ha}^{-1}\right)\right]$ between the row at planting was used for summer weed control. Plants were hand transplanted on $20 \mathrm{M}$ ay.

Tomatoes were harvested once per week for 10 weeks. T otal marketable yields of fruit (U.S. no. 1, 2, and 3 ) from the two surface tilled treatments were lower than yields from the four conservation-tillage treatments (Fig. 4). The plow/ disc and rotavate treatments produced 34.6 and 33.4 ton/ acre ( 77.5 and $\left.74.8 \mathrm{t} \cdot \mathrm{ha}^{-1}\right)$, respectively. The remaining four treat- mentsusing varying degrees of $C T$ had yields of fruit in the following order: strip rototill $<$ no till $<$ strip till =subso $i$ [37.5, 38.6, 39.8, and 39.9 ton/ acre $\left(84.0,86.5,89.2\right.$, and $\left.89.4 \mathrm{t} \cdot \mathrm{ha}^{-1}\right)$, respectively].

\section{Cover crop residue effects on strip-till vegetables}

The following four strip-tillage experiments were established to compare cover crop residue effect on vegetableyield and soil temperatures. Cover crops for each experiment were established in the previous fall by discing the field before planting. Cover crops used at the following rates: rye (Secalecer eale L.) at $100 \mathrm{lb} / \mathrm{acre}\left(112.1 \mathrm{~kg} \cdot \mathrm{ha}^{-1}\right)$, wheat (Triticum a estivum L.) at $100 \mathrm{lb} /$ acre, ryegrass (Lolium multiflorum Lam.) at $25 \mathrm{lb} /$ acre $\left(28.0 \mathrm{~kg} \cdot \mathrm{ha}^{-1}\right)$, austrian winter pea [Pisum sativum subsp. arvense( $L$.) Poir.] at $45 \mathrm{lb} / \mathrm{acre}(50.4$ $\mathrm{kg} \cdot \mathrm{ha}^{-1}$ ), hairy vetch (Vicia villosa Roth) at $35 \mathrm{lb} /$ acre $\left(39.2 \mathrm{~kg} \cdot \mathrm{ha}^{-1}\right)$, and crimson clover (Trifoli um incarnatum L.) at $30 \mathrm{lb} /$ acre $\left(33.6 \mathrm{~kg} \cdot \mathrm{ha}^{-1}\right)$. A mulch treatment wasincluded that used wheat straw applied after planting at a rate of $7000 \mathrm{lb} /$ acre $\left(7846 \mathrm{~kg} \cdot \mathrm{ha}^{-1}\right)$. We used a Bush $\mathrm{H}$ og Ro-till for strip tillage and plowing and irrigation techniques as described in the tillage section.

Tомато. A fresh market tomato experiment wasestablished on thesame soil type as the tillage experiments. Plots were three rows wide and $30 \mathrm{ft}$ $(9.1 \mathrm{~m})$ long with abetween-row plant spacing of $5 \mathrm{ft}(1.5 \mathrm{~m})$ and in-row spacing of $2 \mathrm{ft}(0.6 \mathrm{~m})$. Fertilizer nitrogen was broadcast surface applied at a rate of $100 \mathrm{lb} /$ acre $\mathrm{N}\left(112.1 \mathrm{~kg} \cdot \mathrm{ha}^{-1}\right)$ $1 \mathrm{~d}$ before planting, and two $50 \mathrm{lb} /$ acre N $\left(56.0 \mathrm{~kg} \cdot \mathrm{ha}^{-1}\right)$ surface banded side dress applications 2 and 4 weeks after transplanting. An application of metribuzin [Sencor 75D F at $1 \mathrm{lb} /$ acre $\left.\left(1.1 \mathrm{~kg} \cdot \mathrm{ha}^{-1}\right)\right]$ and napropamide [Devrinol 50WP at $2 \mathrm{lb} /$ acre $(2.2$ $\left.\mathrm{kg} \cdot \mathrm{ha}^{-1}\right)$ ] between the rows at planting in the various experiments were seeded

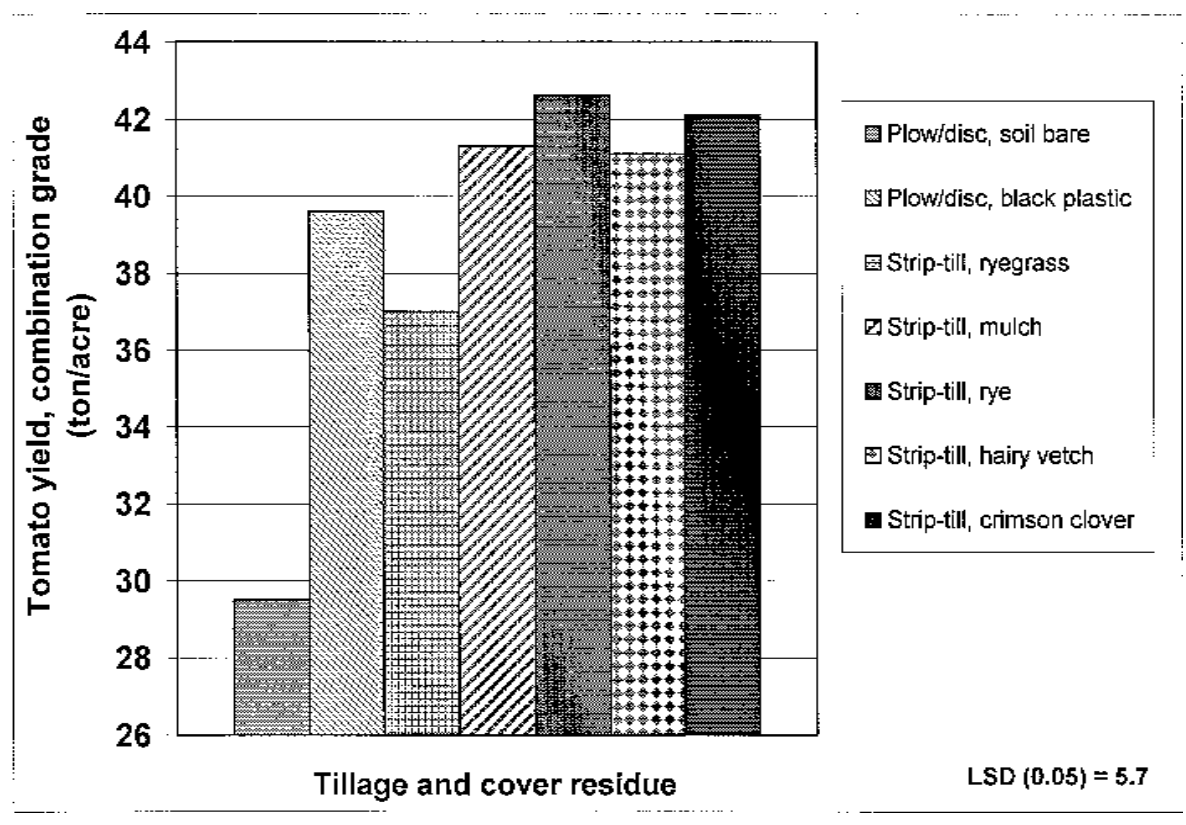

Fig. 5. Effect of plow/disc and strip-till culture with various types of cover residue on tomato yields; 1 ton/acre $=2.24$ th ha ${ }^{-1}$. 


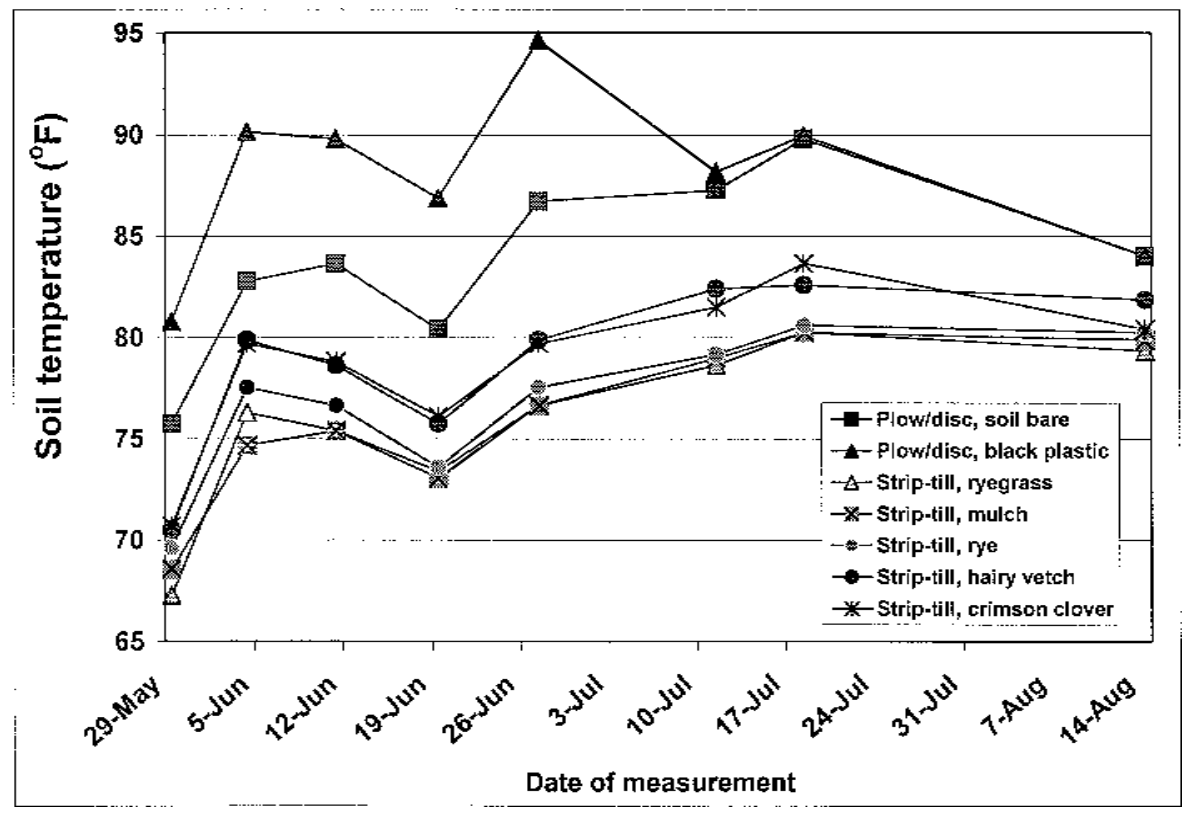

Fig. 6. Effect of plow/disc and strip-till culture with various mulches of black plastic and cover crop residue on soil temperatures during the 1985 tomato growing season. Soil temperature at 4-inch $(10-\mathrm{cm})$ depth; ${ }^{\circ} \mathrm{C}=5 / 9\left({ }^{\circ} \mathrm{F}-32\right)$.

was used for summer weed control. Cover crop burn down was performed 2 weeksbeforeplanting, using paraquat at $1 \mathrm{qt} /$ acre $\left(2.3 \mathrm{~L} \cdot \mathrm{ha}^{-1}\right)$. 'M ountain Pride' tomato plants were hand transplanted on $22 \mathrm{M}$ ay. Cover crop biomass production was $3471,4487,5995$, and $6441 \mathrm{lb} /$ acre $(3888,5025,6714$, and $7214 \mathrm{~kg} \cdot \mathrm{ha}^{-1}$ ) for hairy vetch, crimson clover, ryegrass, and rye, respectively, at spring desiccation.

Tomatoes were harvested once per week for 10 weeks. Combination grade (U.S. no. 1 and 2) fruit yield from the plow/ disc, soil bare treatment waslowest at 29.5 ton/ acre(66.1 t. ha ${ }^{-1}$ ) (Fig. 5). The remaining treatments where some type of mulching system was used all had higher yields. Theplow/ disc, black plastic treatment produced fruit at $39.6 \mathrm{ton} /$ acre (88.7 t.ha $\left.{ }^{-1}\right)$ and thestrip-till treatmentswith various covers were in the order: ryegrass $<$ hairy vetch $<$ mulch $<$ crimson clover < rye [37.0, 41.1, 41.3, 42.1 , and 42.6 ton/ acre $(82.9,92.1$, $92.5,94.3$, and $95.4 \mathrm{t} \cdot \mathrm{ha}^{-1}$ ), respectively].

Soil temperature measurements [1 $\mathrm{ft}(0.3 \mathrm{~m})$ from the plant in the between-row location at a depth of 4 inches $(10 \mathrm{~cm})$ ] were related to the amount of residue on the soil surface from the various treatments of tillage and cover residue. Both the plow/ disc with black plastic and the plow/ disc with bare soil treatments were consis-
Cabbage. The first cabbage ' $R$ io Verde' experiment was planted in the same field and soil type as the tillage experiments. The second cabbage experiment was planted near the first (same soil series) the following year. These experiments determined the effect of cover crop residue and strip tillage on cabbageyield. Both cabbage experiments were established in early summer on $30 \mathrm{M}$ ay and $20 \mathrm{M}$ ay (Expts. 1 and 2, respectively). All cabbage transplants were planted by hand into the strip-till cover crop treatments using a hand trowel. Plotswere $30 \mathrm{ft}$ (9.1 $\mathrm{m})$ long and four rows wide with a between-row spacing of 36 inches ( 91 $\mathrm{cm})$ and in-row spacing of $1 \mathrm{ft}(0.3 \mathrm{~m})$. Fertilizer nitrogen was broadcast surface applied at a rate of $80 \mathrm{lb} /$ acre $\mathrm{N}$ $\left(89.7 \mathrm{~kg} \cdot \mathrm{ha}^{-1}\right) 1 \mathrm{~d}$ before planting and $35 \mathrm{lb} /$ acre N (39.2 kg.ha-1) as a surface banded side dress 2 weeks after transplanting. An application of napropamide [Devrinol 50WP at 2 $\mathrm{lb} /$ acre $\left.\left(2.2 \mathrm{~kg} \cdot \mathrm{ha}^{-1}\right)\right]$ broadcast over the entire plot and oxyfluorfen [ Goal $1.6 \mathrm{E}$ at $0.5 \mathrm{lb} /$ acre $\left.\left(0.6 \mathrm{~kg} \cdot \mathrm{ha}^{-1}\right)\right]$ applied between the rows $1 \mathrm{~d}$ after planting was used for summer weed control for both experiments. Glyphosate [Roundup at $2 \mathrm{qt} /$ acre $\left(4.7 \mathrm{~L} \cdot \mathrm{ha}^{-1}\right)$ ] was applied to the winter cover crops. Cover crop biomass production was $4007,4309,5179,7769$, and 10,772 $\mathrm{lb} /$ acre $(4488,4826,5800,8701$, and $\left.12,065 \mathrm{~kg} \cdot \mathrm{ha}^{-1}\right)$ for austrian winter pea, hairy vetch, crimson clover,

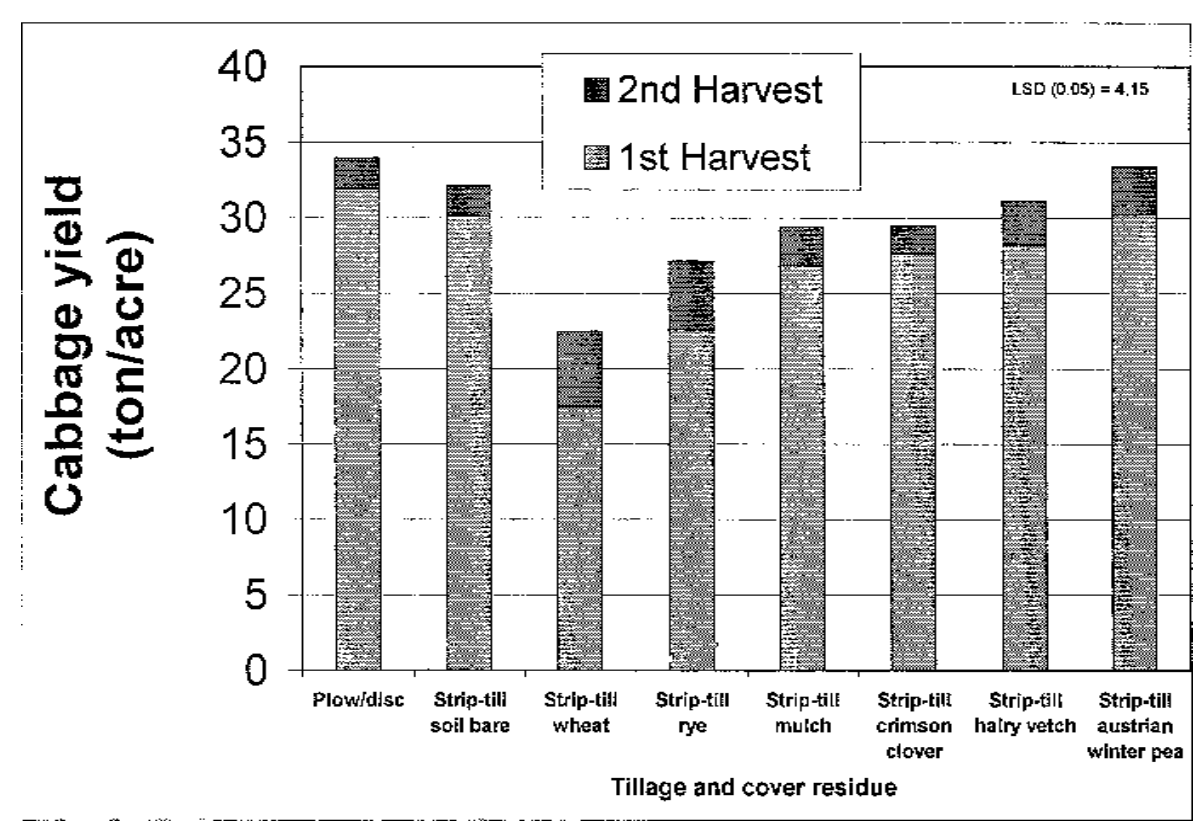

Fig. 7. Effect of plow/disc and strip-till culture with various grass and legume cover crop residue on cabbage yields; 1 ton/acre $=2.24 \mathrm{t} \cdot \mathrm{ha}^{-1}$. 


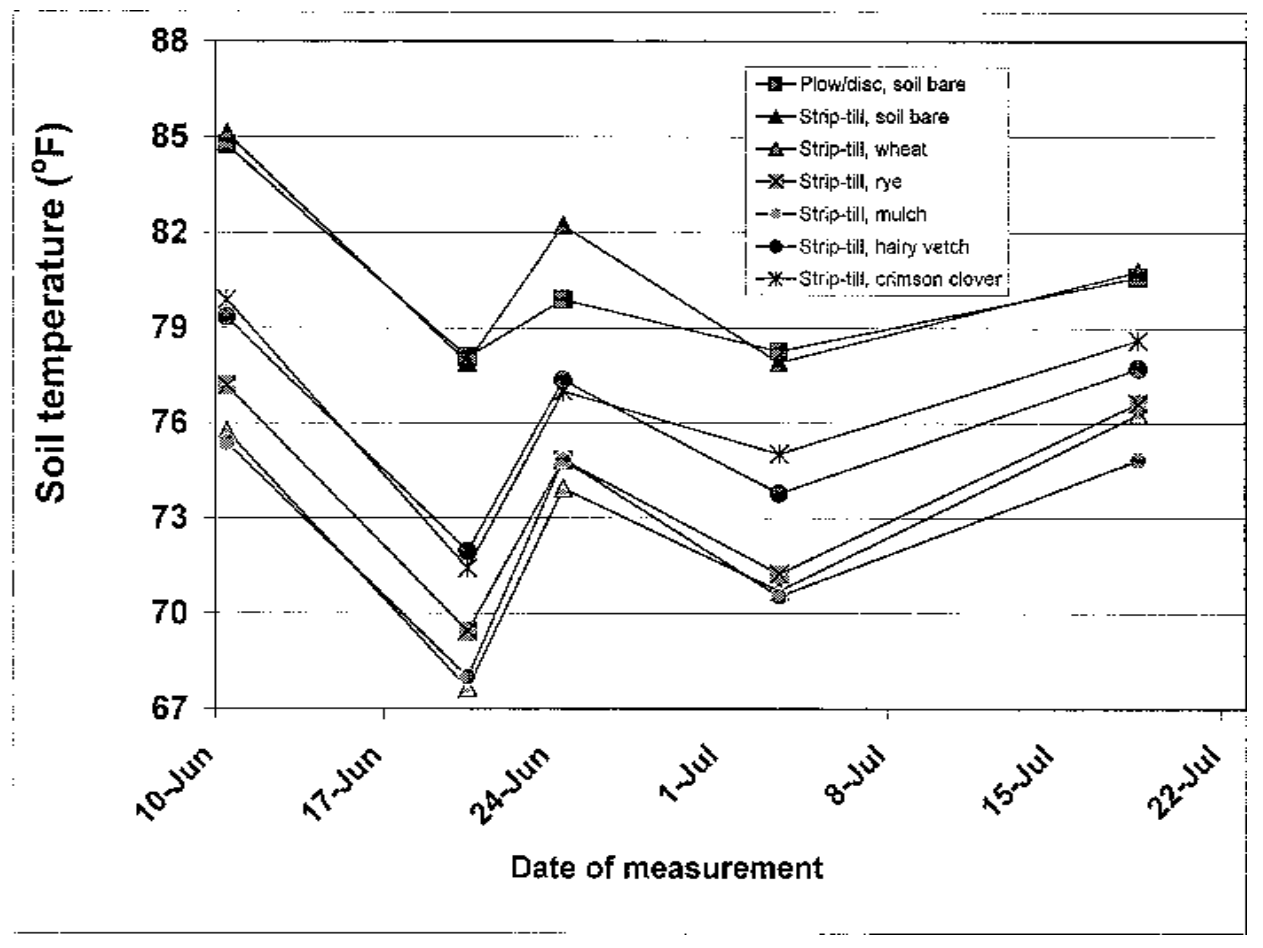

5507 , and $5715 \mathrm{lb} /$ acre (4201, $4863,5601,6168$, and 6401 $\mathrm{kg} \cdot \mathrm{ha}^{-1}$ ) for austrian winter pea, hairy vetch, crimson clover, wheat, and rye, respectively, at spring desiccation. T otal cabbage yields for this experiment were similar to those of the first cabbage experiment. The strip-till bare soil treatment had the highest yields, and the cover residue treatments were in the following order: hairy vetch $>$ crimson clover > austrian winter pea $>$ wheat $>$ rye (Fig. 9). Similar to Expt. 1, the strip-till treatments with the legume cover residue produced morecabbagethan the grass cover residue treatments. In the first harvest (13 Aug.), yields were extremely low in the grass cover residues, and greatest in the crimson clover and hairy vetch residue treatments. The following week, second harvest (20 Aug.) yields continued to improve in all treatments, with the rye residue treat-

Fig. 8. Effect of plow/disc and strip-till culture with various grass and legume cover crop residues on soil temperatures during the 1986 cabbage growing season. Soil temperature at 4-inch $(10-\mathrm{cm})$ depth; ${ }^{\circ} \mathrm{C}=5 / 9\left({ }^{\circ} \mathrm{F}-32\right)$.

rye, and wheat, respectively at spring desiccation. Soil temperatures were taken at a 4-inch (10-cm) depth in a between-row location.

The first and second harvests of the first cabbage experiment occurred on 15 and 22 Aug., respectively. The plow/ disc bare ground treatments produced the greatest yield for both the initial harvest and total harvest (Fig. 7). The strip-till bare soil treatment also produced high yieldsthat were only slightly lower than the plow/ disc treatment. These two treatments produced the warmest soils during early summer (Fig. 8). Cabbageyieldsfrom thestrip-till treatments with cover residue were in thefollowing order: Austrian winter pea $>$ hairy vetch $>$ crimson clover $>$ mulch $>$ rye $>$ wheat. Wheat residue with strip tillage produced the lowest yields of all treatments in the first harvest, but yields increased the following week. Soil temperatures for all treatmentswith cover residuewere lower than soils left bare (Fig. 8). The two legume cover residue treatments were continuously warmer than the mulch or two grass cover residue treatments.
The second cabbage experiment did not have a plow/ disc or strip-till mulch treatment. Cover crop biomass production was 3751, 4342, 5001, ment having the lowest yield. The rye residue treatment yield improved the final week of harvest, but still remained lowest after the third harvest (26 Aug.).

Pотато. 'Atlantic' potato wasused to determine the effect of cover crop and tillage on potato tuber yield. This experiment was established on a

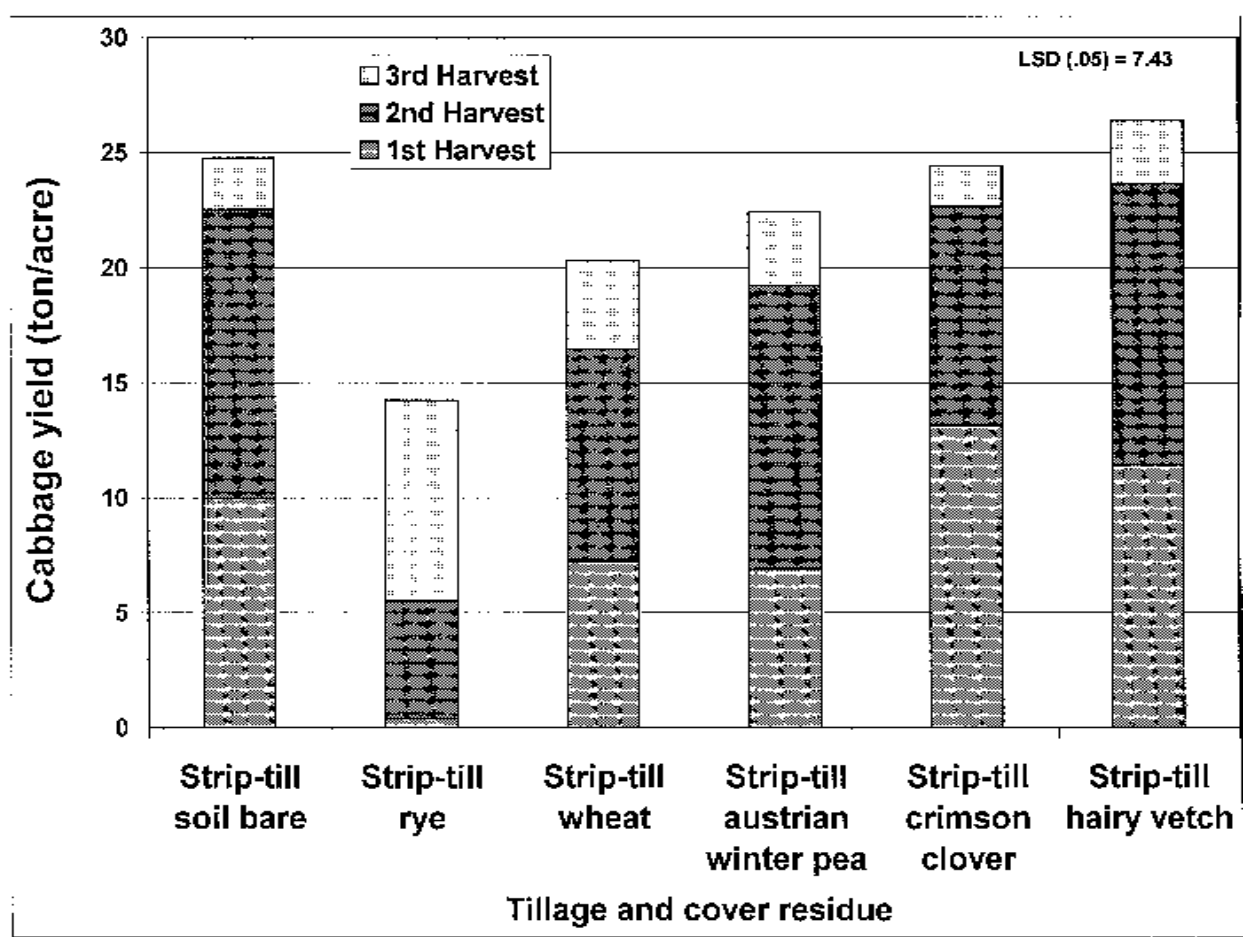

Fig. 9. Strip-till cabbage yields as affected by grass and legume cover crop

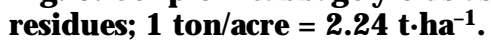




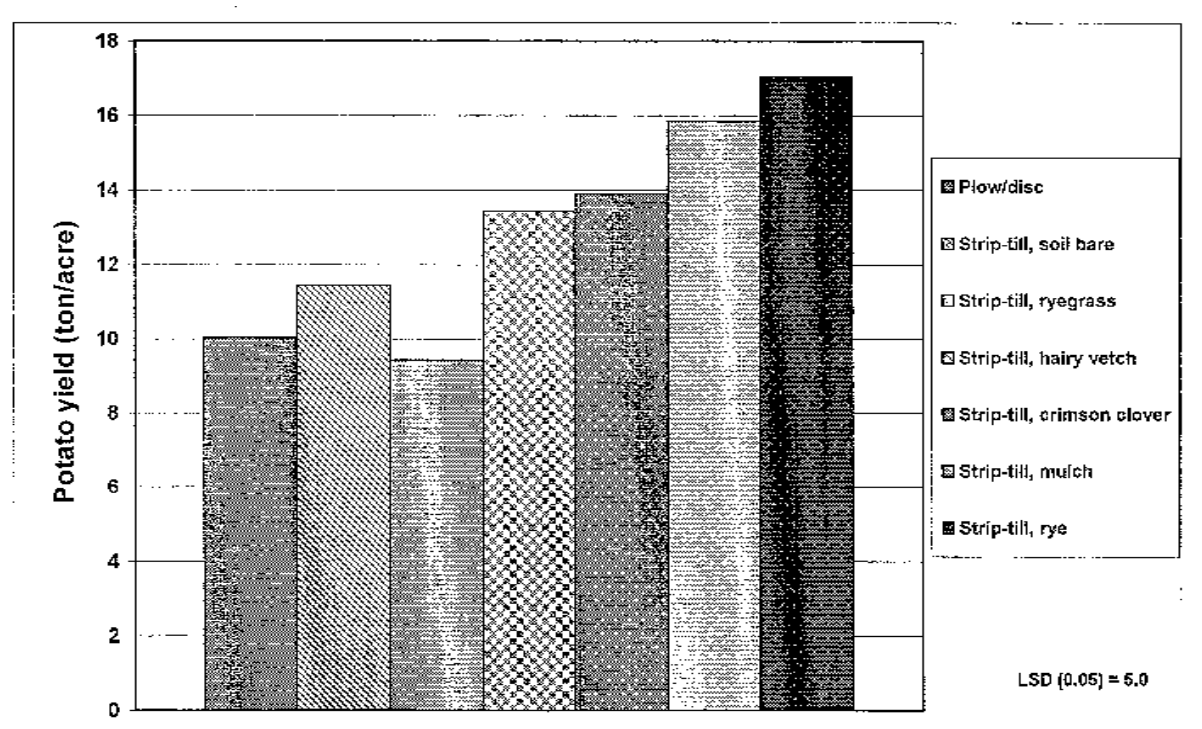

Tillage and cover residue

Fig. 10. The effect of plow/disc and strip-till culture with grass and legume cover crop residues on I rish potato yields; 1 ton/acre $=2.24$ th ha ${ }^{-1}$.

$\mathrm{H}$ ayesvilleloam soil (clayey, kaolinitic, mesic Typic Kanapludults). Plots were four rowswideand $35 \mathrm{ft}$ ( $10.7 \mathrm{~m}$ ) long with a between-row plant spacing of 4 $\mathrm{ft}(1.2 \mathrm{~m})$ and in-row spacing of $1 \mathrm{ft}$ $(0.3 \mathrm{~m})$. Fertilizer nitrogen was broadcast surface applied at a rate of $160 \mathrm{lb} /$ acre $\mathrm{N}\left(179.3 \mathrm{~kg} \cdot \mathrm{ha}^{-1}\right) 5 \mathrm{~d}$ before planting. An application of metolachlor [D ual at $\left.2.5 \mathrm{qt} / \mathrm{acre}\left(5.8 \mathrm{~L} \cdot \mathrm{ha}^{-1}\right)\right]$ and linuron [ $\mathrm{L}$ orox $50 \mathrm{D} \mathrm{F}$ at $2 \mathrm{lb} /$ acre $(2.2$ $\left.\mathrm{kg} \cdot \mathrm{ha}^{-1}\right)$ ] was broadcast over the entire plot for summer weed control. Paraquat at $1 \mathrm{qt} /$ acre $\left(2.3 \mathrm{~L} \cdot \mathrm{ha}^{-1}\right)$ was applied to the winter cover crop 2 weeksbeforeplanting. C ut pieceswere hand planted on $8 \mathrm{M}$ ay. Cover crop biomass production was 3100,3125 , 2850,4675 , and $7025 \mathrm{lb} /$ acre $(3472$, $3500,3192,5236$, and $\left.7868 \mathrm{~kg} \cdot \mathrm{ha}^{-1}\right)$ for hairy vetch, crimson clover, ryegrass, wheat, and rye, respectively, at spring desiccation.

Potato yieldsresponded positively to the mulch conditions provided by the strip-till residue (Fig. 10). Potato yields decreased with cover crop residues as follows: rye $>$ mulch $>$ crimson clover $>$ hairy vetch $>$ bare so il $>$ plow/ disc >ryegrass. O nly the strip-till ryegrass treatment yielded lower than the two treatments with bare soil on the surface.

\section{Discussion}

SHORT SEAson Vegetable CROPS. These experiments showed a repeated pattern of greater vegetableyieldsfrom short season crops that had a high degree of tillage. In both tillage experiments with broccoli, the plowed/ disc treatment produced greater yields than the mulched CT treatments. In the snap bean experiment, early harvest resultsshowed morematurebeans on the first harvest from the plowed/ disc treatment, and not until the fifth harvest (15 d later) did the weight of beans in the strip-till and no-till treatments increase over the plowed/ disc treatment. This lack of earliness from the $C T$ treatments was also seen in the two cabbage experiments with various cover residues with strip tillage. In both of these experiments, higher cabbage yields were produced from treatments that left the surface bare (the strip-till soil bare and the plow/ disc treatments) or had legume residues with strip tillage (Figs. 7 and 9).

Soil temperatures were positively correlated with yield, with greater soil temperatures during the growing season occurring in the same treatments with highest yields (Fig. 8). Soil temperatures were lower in strip-till treatments that used a grass residue as a surface mulch. The lowest soil temperature measurements during the growing season occurred in the striptill mulch treatment, yet this treatment produced cabbage yields similar to the strip-till crimson clover and vetch residue treatments, but lower than the strip-till bare soil treatment. The strip-till mulch treatment did not have a cover crop grown in the soil during the winter (similar to the striptill bare soil), but had mulch added at planting. Thus, the lower yields compared to the strip-till bare soil treatment was probably due to the lower soil temperature. The strip-till mulch treatment produced greater cabbage yields than the strip-till rye or wheat residuetreatments. Thismay havebeen due to the removal of soil nitrogen during the spring by the rye and wheat cover crop (more so than the legume cover crops), leaving soil inorganic nitrogen levels lower at planting in grass cover crop treatments.

Full-season Vegetable crops. We selected winter squash, tomatoes, and potatoes as full season crops to compare degree of tillage and surface residue mulch with strip tillage. In our winter squash experiment comparing degree of tillage, wefound little difference among the three tillage treatments for both acorn and butternut squash (Fig. 2). Although higher yields were reported with the two forms of CT in butternut squash, the variability was high, and no statistical differences were found. Tomato yields also were high in treatments with various forms of CT that had a barley residue mulch on the soil surface, whereas the two cultivated treatments (plow/ disc and surface rototill) had the residue tilled in and produced lower tomato yields. The other tomato experiment with various cover residues with strip till compared to plowed with bare soil or black plastic also produced greater yields with various forms of mulch (added mulch, killed mulch, and black plastic) and lower yields where the soil was left bare. Soil temperature measurements from this experiment produced similar results as the soil temperaturemeasurementsin the cabbage experiment, in that the cultivated treatment with black plastic had thehighest soil temperaturescompared to thestriptill residue treatments and higher early season temperatures compared to the plow/ disc bare soil treatment. A similar pattern of warmer soil temperatures with legume residues compared to the mulch or grass cover crops was observed.

Potato yields increased as residue mulch increased, showing a positive response to all forms of mulch (except for ryegrass). Visual observations of thetilled plotslatein the season showed early senescence of the potato vines 
due to higher soil temperatures and reduction of soil water in these two treatments, possibly reducing the growing season length for these two treatments and favoring the mulch treatments that had greater soil moistureand cooler soil surfacetemperatures (during the warm part of the summer).

\section{Literature cited}

Beste, C.E. 1973. E valuation of herbicides in notill planted cucumbers, tomatoes, and lima beans. N.E. Proc. Weed Sci. Soc. 7:232-239.

Bottenberg, H., J. M asiunas, and C. Eastman. 1999. Strip tillage reduces yield loss of snapbean planted in rye mulch. H ortT echnology 9(2):235240 .

Cambell, W.F. and J.L. Anderson. 1980. Effects of no-tillage and herbicides on carrot and onion seed production. H ortScience 15:662-664.

Coolman, R.M . and G.D. H oyt. 1993. The effects of reduced tillage on the soil environment. $\mathrm{H}$ ortTechnology 3(2):143-145.

Emerson, R.A. 1903. Experiments in mulching garden vegetables. N ebr. Agr. Expt. Sta. Bul. 80.

Estes, E.A., W.A. Skroch, T.R. Konsler, P.B. Shoemaker, and K.A. Sorensen. 1985. N et economic values of eight soil management practices used in stake tomato production. J. Amer. Soc. H ort. Sci. 110(6):812-816.

H egwood, J r., C.P., G.R.T upper, and E.L. M oore. 1978. M inimum tillage for tomatoes. Amer. Veg. Grower 26:16, 18.

H oyt, G.D. 1984. The effect of cover crops on strip-till vegetable and tobacco production. Soil Sci. Soc. N.C. Proc. 27:10-20.

H oyt, G.D., A.R. Bonanno, and G.C. Parker. 1996. I nfluence of herbicides and tillage on weed control, yield, and quality of cabbage (Brassica oleracea L. var. capitata). Weed Technol. 10:5054.

H oyt, G.D. and W.L. H argrove. 1986. Legume cover crops for improving crop and soil management in the southernU .S. H ortScience21(3):397402.

H oyt, G.D. and T.R. Konsler. 1988. Soil water and temperature regimes under tillage and cover crop management for vegetable culture, p. 697702. Proc. 11th Intl. Conf., I ntl. Soil Tillage Res. Org., Edinburgh, Scotland.

H oyt, G.D. and D.W. M onks. 1996. Weed management in strip-tilled I rish potato and sweetpotato systems. H ortT echnology 6:238-240.

H oyt, G.D., D.W. Monks, and T.J. Monaco. 1994. Conservation tillage for vegetable production. H ortT echnology 4(2):129-135.

H oyt, G.D. and J.F. Walgenbach. 1995. Pest evaluation in sustainable cabbage production systems. H ortScience 30:1046-1048.

Knavel, D.E., J. Ellis, and J . M orrison. 1977. The effects of tillage systems on the performance and elemental absorption by selected vegetable crops. J. Amer. Soc. H ort. Sci. 102(3):323-327.

Knavel, D.E. and J.W. H erron. 1981. I nfluence of tillage system, plant spacing, and nitrogen on head weight, yield, and nutrient concentration of spring cabbage. J. Amer. Soc. H ort. Sci. 106(5):540545.

Knavel, D.E. and J.W. H erron. 1985. Effect of sudan grass on yield and elemental content of cabbage. H ortScience 20(4):680-681.

Knavel, D.E., J.W. Herron, and G.M. White. 1985. N o-till popcorn performs as well as conventionally grown popcorn. HortScience 20:136137.

L ugo-M ercando, H .M ., J. Badillo-Feliciano, and F.H. O rtiz-Alvarado. 1984. Effects of no-tillage and various tillage methods on yields of maize, field beans and pepper grown on a mollisol in southern Puerto Rico. J. Agr. U niv. P.R. 68:349354.

Morrison, Jr., J.E., D.C. M ilbocker, W.O. Atkinson, and J.H. Smiley. 1973. Transplanter modification and survival of transplants under notillage conditions. H ortScience 8:483-485.

M orse, R.D. 1993. Components of sustainable production systems for vegetables-C onserving soil moisture. H ortT echnology 3(2):211-214.

M orse, R.D. and D.L Steward. 1985. C over crops for no-tillage production of cabbage and broccoli. Veg. Growers N ews. 39(3):1, 4.

M orse, R.D. and D.L. Steward. 1986. N o-tillage production of broccoli and cabbage. Appl. Agr. Res. 1(2):96-99.

M orse, R.D., C.M. Tessore, W.E. Chappell, and C.R. O 'D ell. 1982. U se of no-tillage for summer vegetable production. Veg. Growers News. 37(1):1.

M undy, C., N.G. Creamer, C.R. Crozier, L.G. Wilson, and R.D. M orse. 1999. Soil physical properties and potato yield in no-till, subsurface-till, and conventional-till systems. H ortT echnology $9(2): 240-247$.

Ranells, N .N . and M .G. Wagger. 1997. N itrogen15 recovery and release by rye and crimson clover cover crops. Soil Sci. Soc. Amer. J. 61:943-948.

SAS Institute. 1988. SAS user's guide: Release 6.03 ed. SAS I nstitute, Cary, N.C.

Wagger, M.G. 1993. Role of cover crops in soil water and nitrogen dynamics. Soil Sci. Soc. N.C. Proc. 36:59-60.

Wilhoit, J.H ., R.D. M orse, and D.H . Vaughan. 1990. Strip-tillage production of summer cabbageusing high residue levels. Appl. Agr. Res. 5(4):338-342. 